\title{
THE CONSTRUCTION OF A MECHANICAL ABILITY TEST FOR AFRICANS IN HIGH LEVEL JOBS
}

\author{
W.C. BOTHA \\ DEPARTMENT OF INDUSTRIAL PSYCHOLOGY \\ UNIVERSITY OF FORT HARE
}

\section{OPSOMMING}

\begin{abstract}
Die snelle groei van die Suid-Afrikaanse bedryfswese het gelei tot tekorte aan tegnies opgeleide werkers. Die blanke bevolking, wat tradisioneel arbeid vir hierdie tipe werksoorte voorsien het, is nie meer in staat om in die al hoe groter aanvraag te voldoen nie. Die Swart werker in Suid-Afrika moes derhalwe in 'n toenemende mate opgelei word om hierdie tipe poste te vul. 'n Behoefte het ontstaan vir 'n objektiewe keuringsinstrument vir gebruik by die keuring van Swart werkers vir tegniese en meganiese werksoorte. Hierdie studie is derhalwe 'n poging om die weg te baan vir die ontwikkeling van so 'n objektiewe keuringsinstrument. 'n Meganiese vermoëtoets is opgestel en die preliminêre standaardisering daarvan is uitgevoer.
\end{abstract}

The socio-economic progress of any country depends on a sufficient supply of labour. South Africa has manpower shortages in many job categories and the need for qualified workers is acute.

The Industrial Revolution has compelled man to expend an increasing amount of his energy on mechanical and technical pursuits. The invention of the steam engine, electricity, telephone, radio and the like, attracted increasing numbers of workers to the manufacturing industry and present-day technological progress has continued to increase the number of industrial and technical workers.

Industrial development in South Africa was initially slow, but the discovery of diamonds and gold stimulated the economy and the subsequent increase in demand for manufactured goods. The mining industry, which has for many decades been the mainstay of the South Africa economy, is still providing stimulation for increased demands for manufactured goods. This, together with a realisation that South Africa will in years to come depend more on manufactured goods for export trade, has created tremendous demands for skilled labour, especially in the mechanical and technical fields. 
Until recently only White workers have been employed in technically more advanced jobs. The reasons for this are many, but notable have been employment restrictions imposed on Black workers by the Government and White Trade Unions.

Present and expected future shortages of trained manpower have caused the relaxation of many restraints barring Black workers for entering various skilled jobs. This, together with the fact that more Blacks are attaining higher school qualifications, has made it possible to train many of them for skilled technical work. Not only the trade unions, but also the Government has realised that the Black man will have a far greater role to play in reducing the acute shortages of skilled labour.

Even though the need for more technically qualified workers is acute, and large numbers of Black workers are available for training in these jobs, many people appear to be sceptical over the Blacks' ability to succeed in these jobs. Biesheuvel (1973) is however of a different opinion and says:

"I do not share the general belief that Africans are basically lacking in mechanical insight".

The increased use of Blacks qualified in technical and mechanical skills has created the need for an objective measurement device for selecting Black workers for jobs in this field. The problem which this study investigates is therefore the development of a device for selecting Black workers for higher level technical and mechanical jobs.

Although certain tests (see test catalogues of the N I P R and H S R C) are available for measuring various aspects of mechanical ability, no tests exist specifically for the purpose of selecting Black workers for higher levels of mechanical work, and although the H S R C and N I P R expressed interest in such a test (as evident from discussions between the author and these two bodies during 1973), no such test has yet been published.

Tests produced by the H S R C and N I P R (1977 catalogues) are available for measuring various subabilities contained in the composite concept of mechanical ability. Amongst these are tests of two and three dimensional spatial relations, numerical and verbal abilities, perceptual abilities and various psychomotor measures. Few of these tests were however constructed specifically for Black populations and since the use of tests, constructed for one culture group, is not recommendable for other culture groups, (Langenhoven, 1963; Anastasi 1961) the need for a test of a sufficiently high level, specifically constructed for Black populations, became essential. 
The construction of tests for Black populations, although in principle not different from test construction for other racial groups, poses certain problems and pitfalls for the test constructor. The language medium that should be used for Blacks, (Moore, 1959), the cultural content of items (Anastasi 1961), paper and pencil tests vs. other tests (Biesheuvel 1949), presentation of tests (Langenhoven 1963), and speed vs. power tests (Biesheuvel 1949), are all factors that require careful analysis before test construction for Black populations can be attempted.

In addition to the numerous variables which have to be considered when tests for Blacks are constructed, the investigator is further faced with a decision on how the concept "mechanical ability" should be defined. Various writers (McCormick and Tiffin 1975; Harrel 1940; Fleishman and Hempel 1954; Nunnally 1970) have concluded that mechanical ability is a composite ability comprising various other subabilities. The particular subabilities included in a test of mechanical ability are dependent on the purpose for which the test is to be used, but most writers (Lawshe and Balma 1966; Nunnally 1970) agree that the concept "mechanical 'ability" can be divided into two broad factors, namely the cognitive and the psychomotor or physical aspects. McCormick and Tiffin (1975) are of the opinion that mechanical ability testing is mainly concerned with the measurement of the cognitive aspects, although they accept that the physical aspects are also important for the successful completion of many mechanical tasks.

Various attempts have been made to measure both the cognitive and the physical aspects of mechanical ability through the use of one instrument (Goodman 1946; Chapman 1948). It can be accepted however, that the cognitive aspects are better measured through paper and pencil type tests while apparatus tests are more suited to measuring physical abilities.

This study was directed at the measurement of certain cognitive aspects of mechanical ability. Although it is accepted that psychomotor abilities are important in many technical and mechanical tasks, the population, of high level Black workers, for which the test was constructed are possibly less dependent on the physical aspects of mechanical ability to be successful in their jobs.

\section{The aim of the study}

The aim of the study was to construct an objective measurement instrument which could be used to select Black workers for high level technical and mechanical jobs. 


\section{Three stages of investigation}

The investigation consisted of three stages of test construction:

- A survey was made of the present use of Black workers in mechanical-type jobs. The survey was undertaken through visits to seven large industrial concerns who had replied to letters sent to 100 firms enquiring whether they employed high-level Black technical and mechanical workers. During the visits job analysis information of various mechanical jobs was acquired.

- A survey of the literature was made to determine which subabilities contained in the composite concept of mechanical ability had been found important by other researchers in similar investigations.

- The construction and validation of a mechanical ability test for high-level Black workers.

\section{An analysis of some mechanical/technical job categories}

Job analyses were undertaken at seven large South African firms. Four firms were visited in the Transvaal, among them a steelmill, a gold mine, and two textile factories. An aluminium products manufacturer and a detergent factory were visited in Natal as well as a textile firm in the Eastern Cape. Various other firms throughout the country supplied detailed job analysis information already existing in their personnel departments. Many other firms supplied brief descriptions of the mechanical and technical jobs currently undertaken by Black workers in their companies.

Ordinary job analysis methods (cf. Lawshe and Balma, 1966, p. 290) were employed. Many workers and supervisors were interviewed and a large number of jobs were observed. Information on the nature and content of various jobs became available. In all, 47 job categories were investigated and the information was tabulated and analysed: Sixteen major tasks were identified as predominant amongst all the jobs, although the following can be regarded as the basic tasks involved in these jobs:

- $\quad$ Reading of dials and meters and manning control points.

- Controlling of a variety of machines through the manipulation of switches and other controls.

- Maintenance of machines and replacement of worn parts. 
- Use of hand tools for most jobs.

- $\quad$ Setting of machines.

- Inspection of finished products and resetting of machines where defective products occur.

- Keeping of records of materials used, changes to machine settings, and production rates/output of machines as well as the writing of reports to supervisors.

The activities performed in these job categories are all of a responsible and reasonably intricate mechanical/technical nature.

The job analysis information indicated that the workers employed all had school qualifications between standards 5 and 10 with at least $70 \%$ having standard 8 certificates. Only a small number of graduates were employed by business equipment firms. Most workers were trained by their respective companies for their specific jobs and only in three cases were workers externally trained.

The investigation into the nature of the various job categories of a mechanical and technical nature mentioned above, yielded a composite picture of the content and requirements of these jobs. Although it would be impossible to investigate every job where Black workers are employed in mechanical tasks, it is believed that the activities identified are common to most mechanical and technical jobs and represent the content of many jobs other than the mere 47 studied here.

\section{Subabilities of mechanical ability identified by other researchers}

A multitude of researchers have over the years endeavoured to identify the various factors or subabilities contained in the concept "mechanical ability". Initially emphasis was placed on the psychomotor aspects of mechanical work. This is not surprising as mechanical jobs in those days made very little intellectual demands on workers if compared to such job categories today.

Tests of mechanical ability were also of an apparatus type (cf. Cox 1928; Keane and O'Connol 1927). Although the psychomotor aspects of mechanical work cannot be termed unimportant, (cf. McCormick and Tiffin 1975; Fleishman and Gaylard 1975), the cognitive factors of mechanical ability have been emphasised more and more. Technical jobs have become less dependent on manipulative skills and intellectual factors have appeared to play an increasing role in mechanical job success. It is therefore not surprising that most 
investigations into mechanical ability, as is the case with this study, are concerned with the cognitive aspects of mechanical ability.

An analysis of the findings of many an investigation into mechanical ability reveals that the following factors are most frequently represented in mechanical ability tests:

Intellectual abilities

Spatial relations

Perceptual ability

Mechanical comprehension

Motor dexterity

Mechanical information (Knowledge)

Harrel (1940) e.g. found by means of a factor analytic study that perceptual and spatial abilities, and manipulative skills are important. Anastasi (1961) discusses various tests of mechanical ability and the factors which they measure. Among these are perceptual abilities, mechanical reasoning, mechanical information, mechanical comprehension and arithmetic, which is important in trade training.

In recent times the use of biographical information has become a popular technique for predicting success in a variety of job categories. A study by Bowd (1973) indicated biographical information to be a factor in predicting mechanical job success. This study used Indians in Canada as subjects.

An endless list of factors can be compiled which have been found predictive of mechanical ability. It can be concluded however, that the major subabilities listed above are prevalent in all these investigations.

\section{The construction of a mechanical ability test}

The aim of the study was to construct a mechanical ability test for selecting Africans for high level mechanical and technical jobs. The study was conducted in three stages, namely the construction and application of a concept test, the construction of a preliminary test based on the results of the first application, and the construction of a final short form of the test consisting of the best test items developed in the previous two stages. 


\section{Choice of subabilities}

The subabilities measured in this study were chosen on the strength of two sets of information. Firstly, the job analyses that were undertaken in industry provided an idea of what abilities were required for job success in mechanical type jobs. Secondly, a review of the literature indicated which results previous researchers had obtained by measuring different subabilities of mechanical ability.

With this pool of information available, it was possible to determine which subabilities would probably play the most important role in the successful completion of the jobs in question. It was decided to measure the following subabilities in order to find an assessment of mechanical ability:

Three-dimensional spatial relations

Two-dimensional spatial relations

Mechanical knowledge

Mechanical problem solving

Afrikaans and English vocabulary

Arithmetic speed

Previous personal contact with mechanical things

\section{Item construction}

With the aim of the test and the nature of the population for which the test was intended in mind, the test items had to qualify on the following points:

(i) Reading and writing had to be limited to a minimum.

(ii) As far as possible, items had to be of a multiple choice type so that testees could choose the correct answer rather than construct their own.

(iii) The items had to be constructed in such a way that testees need not carry over the answer from the test booklet to special answer-sheets.

(iv) The test content had, where possible, to have a cultural flavour.

(v) Test instructions had to be kept to a minimum. The test therefore, had to be so easy that the testees could immediately see what was expected of them.

With the foregoing in mind, test content was systematically secured for each subtest. A method of content outline was used for this purpose. The content outline is a matrix which enables the test constructor to list the different activities performed and to break each activity down into task elements. Against each element on the matrix appears the relative importance 
of each element. This ensures that the more frequent and important elements of the job receive more attention in the test content than less important elements.

By using the foregoing method, content for each subtest was secured. A sample item of each test, together with a short description is presented.

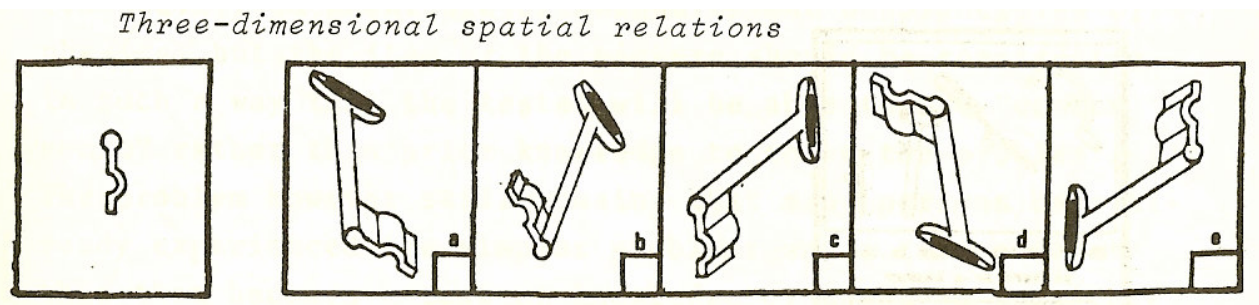

Figure 1: 3-D Spatial Relations

In an attempt to move away from the usual "blocks that fit into each other" concept that is so often used for this type of test, the idea of keys and keyholes was used. It will be noted that the keyholes are two-dimensional, but the task, namely, turning the keys in the mind's eye to find the key that fits, is three-dimensional in nature.

Two-dimensional spatial relations

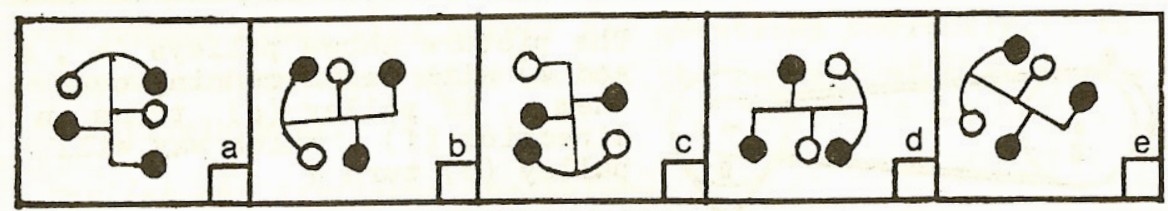

Figure 2: 2-D Spatial Relations

These items consist of five abstract figures which are all alike but one which is "flipped over". The task is for the testee to find the one figure that differs from the other four. The figures may only be turned in the plane of the paper, i.e. from the left to right.

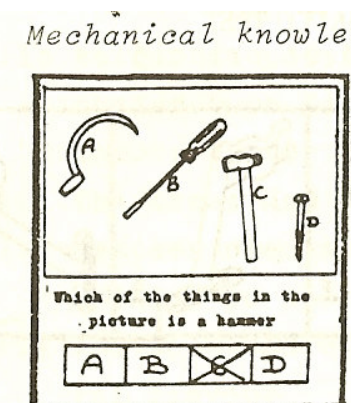

Figure 3: Mechanical knowledge 
The task in this test is very easy in that the testee needs only to recognise the answer by looking at the picture of objects and tools. An attempt has been made to represent various trades in this test, e.g. electrical, plumbing, carpentry, mechanical work, etc.

Mechanical problem solving

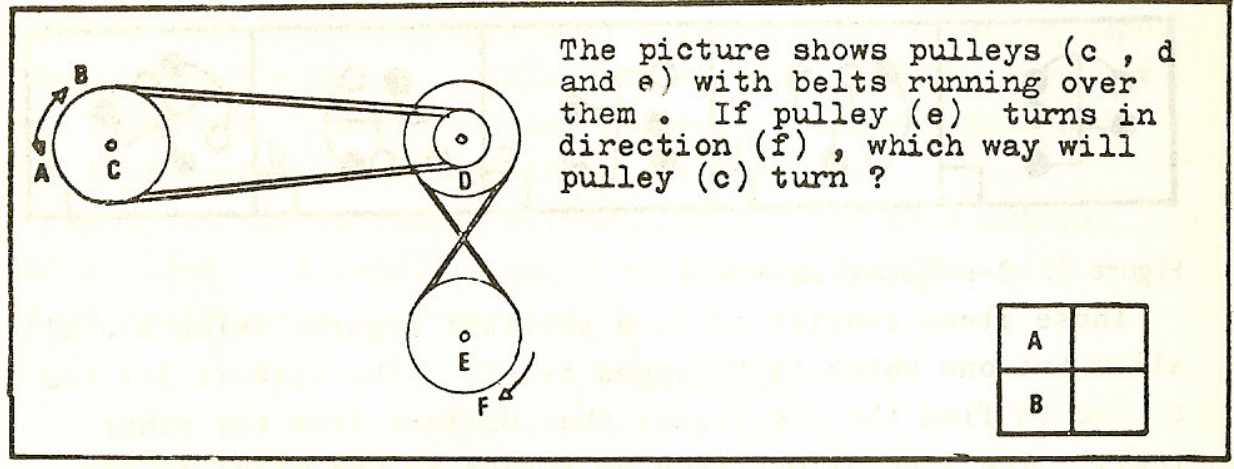

Figure 4: Mechanical problem solving

Content for this type of test was difficult to find. The author is of the opinion that problems used should not rely too heavily on knowledge of mechanics and of principles of physics, but the item or the picture should be constructed in such a way that the testee will be able to use "common sense" rather than prior knowledge to solve the problem. The problem however still remains that many persons have already experienced the simpler problems and a test such as this then becomes a test of knowledge or merely a recollection task.

Arithmetic speed
\begin{tabular}{|l|l|l|l|l|l|l|}
\hline $1 \frac{1}{2}+\frac{3}{4}$ & $=$ & $\frac{3}{4}$ & $\frac{7}{4}$ & $2 \frac{1}{2}$ & $1 \frac{3}{4}$ & none of these \\
\hline
\end{tabular}

Figure 5: Arithmetic Speed

The purpose of a speed test is not to measure the ability to solve problems, or to use the test content in any other way. The basic aim of a speed test is to determine the rate at which the test content can be manipulated. Everyone, given enough time, will answer all questions correctly. As can be seen from the figure above, the content of this test is relatively easy.

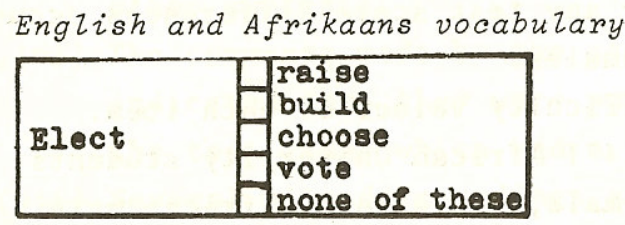

Figure 6: English Vocabulary

Half of the items of this test is in English and the other half in Afrikaans. The task is easy. The testee has to find the word amongst the five on the right which has the same meaning as the one on the left. 


\section{Biographical information}

Twenty-nine personal history items were constructed which are related to the testees' previous contact with mechanical and technical things. Amongst others questions regarding previous experience of carpentry, technical magazines and books read, ownership of bicycles, radios, etc. This questionnaire was based on one used by Bowd (1972) who found it useful in selecting workers for mechanical jobs.

\section{The concept test battery: application and results}

The concept test battery consisted of seven subtests made up of items similar to those discussed above. The aim of this form of the test was:

(i) To determine the time required to complete each subtest.

(ii) To determine whether the test instructions were clear.

(iii) To determine whether the test content was acceptable to the testees.

(iv) To determine whether any test score differences occur between males and females.

(v) To determine the difficulty values of each item.

The test was applied to 471 African University students, of whom thirty five were female, and also 18 African male factory workers in the East London area. The tests were applied by an African Masters degree student at the University of Fort Hare.

The testees were asked to comment on the test after the testing session and these comments together with other questions asked during testing were noted.

The results of the application of the concept test battery can be summarised as follows:

(i) The time required to complete the test battery was found to be 105 minutes.

(ii) It was determined that the testees in this sample required approximately 24 seconds to complete one arithmetic problem.

(iii) The difficulty values for each item were computed. The values ranged from very difficult to very easy.

(iv) The total sample was divided into two groups by using a criterion of internal consistency. The significance of the differences in proportions between the responses of the high and low criterion groups were computed for each item. Almost all the items showed significant discriminatory power. 
(v) It appeared that females performed better on the vocabulary subtest while the males performed better on the other subtests.

(vi) The comments made by the students after being tested, indicated that they were particularly negative towards the test items which had a cultural loading.

(vii) Several misunderstandings arose from the test instructions and a few items were unclear to the testees.

\section{The preliminary test battery}

The information obtained in the previous application made it possible to construct a preliminary test battery. This test battery included all the improvements called for and the arrangement of test items from the most easy to the most difficult. Test time-limits were set for each subtest and a comprehensive tester's manual was devised to ensure that the tests would be uniformly applied. As will be noted below, one of the aims of this test was to determine whether the testees would prefer to take the tests in their home language or in English. For this purpose all the tests and the manual were translated into three African languages: Xhosa, Zulu and Sotho.

\section{Aims of the preliminary test battery}

The aims of the preliminary test can be summarised as follows:

- $\quad$ To determine whether the testees would prefer taking the test in their homelanguages.

- To draw a representative sample from workers employed in mechanical type jobs in industry and to apply the test to them.

- To obtain criterion information for each testee participating.

- To analyse the obtained data in order to compute the following: Item validity Item difficulty

Distractor information

The relationship between tests, the criterion and total scores Internal consistency of the test. 


\section{The sample}

Mention has already been made of the difficulty in acquiring a large enough sample for the study. Nevertheless a total of 394 tests were completed, but of this number, 50 booklets could not be used as they were not completed satisfactorily. The sample included only male African workers employed in mechanical type jobs in mining, metal, textile and business equipment industries. The job categories included were: maintenance and repair staff, high level machine operators, computer technicians, tradesmen, artisans' assistants and apprentices. The different African language groups were well represented as the testees were drawn from all four provinces.

\section{The criterion}

Objective criterion measures for the different jobs represented in the sample were not available and would most probably not have been comparable in any case. It was decided therefore to make use of a supervisor's rating of the testees on six items related to mechanical work success. A nine-point scale was used and a total criterion score for each testee was computed.

\section{Item analysis}

The median of the supervisors' ratings was used to divide the sample into high and low criterion groups. Through the use of a tetrachoric correlation coefficient, the responses of both criterion groups on each item were computed.

The same procedure was carried out a second time, but in this case the median of the total-score distribution was used as the criterion of success on which high and low groups were established. The first computation was related to an external criterion of success, the second based on a criterion of internal consistency.

From the results obtained, (see appendix A) it appears that most items were valid and only very few items showed no discriminatory power at all. An important finding at this stage was that the Afrikaans vocabulary test appeared to have very little validity. This was not surprising as $35 \%$ of the sample did not attempt to answer this test.

\section{Item difficulty}

The difficulty value of each item was computed by determining the proportion of the high and low groups who answered the item correctly (see appendix A). This analysis 
indicates that the test battery was reasonably easy. The Afrikaans vocabulary test was evidently too difficult. Most of other tests had average difficulty values around ,60.

\section{Distractor analysis}

The items that were used in the test battery were all of the multiple-choice type. In other words, testees had to select their answer from a number of possible answers. One of the advantages of multiple choice test items is that they reduce the effects of guessing. If an item has only two choices, there is a $50 \%$ chance of guessing the answer correctly. If there are five choices, the chance is only $20 \%$ and so on. The item has only one correct answer, the other choices being given so as to distract the testee's attention from the correct answer. The distractors must therefore not obviously deviate from the correct answer otherwise the testee will see that the distractor is obviously wrong and thereby increase the effects of guessing. The purpose of distractor analysis is therefore to determine whether each distractor of each item is making a contribution towards attention of the testee who cannot arrive at the correct answer without guessing. (See Botha, 1976).

This analysis required that the percentage of responses to each distractor used in the test be determined (see appendix B), and it appeared that several items contained distractors that were not effective enough. These distractors were changed and improved before their inclusion in the final test.

\section{Analysis of the biographical inventory}

Biographical inventories have been used for many purposes, but have probably been used often for the selection of sales-staff (Botha, 1972). A study conducted by Bowd (1972) in Canada, demonstrated that the biographical inventory could be used successfully to predict mechanical ability. Based on this study, a biographical inventory was included in the battery and after analysis ten biographical factors emerged as predictive of the mechanical ability criterion used in this study.

Table 1 presents the factors and statistics for each. 
TABLE 1

AGE: ANALYSIS OF BIOGRAPHICAL INFORMATION

\begin{tabular}{|l|c|c|c|c|c|c|}
\hline Item & $\begin{array}{c}\text { Proportion } \\
\text { High Group }\end{array}$ & $\begin{array}{l}\text { Proportion } \\
\text { Low Group }\end{array}$ & $\begin{array}{c}\text { Omega- } \\
\text { value }\end{array}$ & $\begin{array}{c}\text { Signifi- } \\
\text { cance }\end{array}$ & $\begin{array}{c}\text { Nett- } \\
\text { weight }\end{array}$ & $\begin{array}{c}\text { Assigned } \\
\text { Weight }\end{array}$ \\
\hline 25 yrs and younger &, 67 &, 34 &, 49 &, $1 \%$ & 8 & 2 \\
26 yrs and older &, 33 &, 66 &, 49 &, $1 \%$ & -8 & 0 \\
\hline
\end{tabular}

SCHOOL QUALIFICATIONS:

\begin{tabular}{|l|c|c|c|c|c|c|}
\hline Item & $\begin{array}{c}\text { Proportion } \\
\text { High Group }\end{array}$ & $\begin{array}{l}\text { Proportion } \\
\text { Low Group }\end{array}$ & $\begin{array}{c}\text { Omega- } \\
\text { value }\end{array}$ & $\begin{array}{c}\text { Signifi- } \\
\text { cance }\end{array}$ & $\begin{array}{c}\text { Nett- } \\
\text { weight }\end{array}$ & $\begin{array}{c}\text { Assigned } \\
\text { lieight }\end{array}$ \\
\hline Sta. 6 and 7 &, 11 &, 71 &, 98 &, $1 \%$ & -19 & 0 \\
Std. 8 &, 89 &, 29 &, 98 &, $1 \%$ & 19 & 2 \\
\hline
\end{tabular}

PREVIOUS JOBS:

\begin{tabular}{|l|l|l|l|c|c|c|}
\hline \multicolumn{1}{|c|}{ Item } & $\begin{array}{l}\text { Proportion } \\
\text { High Group }\end{array}$ & $\begin{array}{l}\text { Proportion } \\
\text { Low Group }\end{array}$ & $\begin{array}{c}\text { Omega- } \\
\text { value }\end{array}$ & $\begin{array}{c}\text { Signifi- } \\
\text { cance }\end{array}$ & $\begin{array}{c}\text { Nett- } \\
\text { weight }\end{array}$ & $\begin{array}{c}\text { Assigned } \\
\text { Weight }\end{array}$ \\
\hline Labourer &, 0005 &, 23 &,- 65 &, $1 \%$ & -5 & 0 \\
Lower technical &, 50 &, 34 &, 23 &, $1 \%$ & 4 & 2 \\
Other &, 48 &, 42 &, 05 & - & 1 \\
\hline
\end{tabular}

DOES YOUR FATHER OWN A BICYCLE?

\begin{tabular}{|l|c|c|c|c|c|c|}
\hline Item & $\begin{array}{c}\text { Proportion } \\
\text { High Group }\end{array}$ & $\begin{array}{c}\text { Proportion } \\
\text { Low Group }\end{array}$ & $\begin{array}{c}\text { Omega- } \\
\text { value }\end{array}$ & $\begin{array}{c}\text { Signifi- } \\
\text { cance }\end{array}$ & $\begin{array}{c}\text { Nett- } \\
\text { weight }\end{array}$ & $\begin{array}{c}\text { Assigned } \\
\text { Weight }\end{array}$ \\
\hline Yes &, 52 &, 88 &, 60 &, $1 \%$ & -9 & 0 \\
No &, 48 &, 12 &, 60 &, $1 \%$ & 9 & 2 \\
\hline
\end{tabular}

FATHER'S OCCUPATION:

\begin{tabular}{|l|c|c|c|c|c|c|}
\hline \multicolumn{1}{|r|}{ Item } & $\begin{array}{c}\text { Proportion } \\
\text { High Group }\end{array}$ & $\begin{array}{c}\text { Proportion } \\
\text { Low Group }\end{array}$ & $\begin{array}{c}\text { Omega- } \\
\text { value }\end{array}$ & $\begin{array}{c}\text { Signifi- } \\
\text { cance }\end{array}$ & $\begin{array}{c}\text { Nett- } \\
\text { weight }\end{array}$ & $\begin{array}{c}\text { Assigned } \\
\text { lieight }\end{array}$ \\
\hline $\begin{array}{l}\text { Teacher } \\
\text { Policeman } \\
\begin{array}{l}\text { Labourer } \\
\text { Driver } \\
\text { Other }\end{array}\end{array}$ &, 31 &, 06 &, 50 &, $1 \%$ & 6 & 2 \\
\hline
\end{tabular}


SCHOOL SUBJECT PREFERENCE

\begin{tabular}{|l|c|c|c|c|c|c|}
\hline \multicolumn{1}{|c|}{ Item } & $\begin{array}{l}\text { Proportion } \\
\text { High Group }\end{array}$ & $\begin{array}{c}\text { Proportion } \\
\text { Low Group }\end{array}$ & $\begin{array}{l}\text { Omega- } \\
\text { value }\end{array}$ & $\begin{array}{c}\text { Signifi- } \\
\text { cance }\end{array}$ & $\begin{array}{c}\text { Nett- } \\
\text { weight }\end{array}$ & $\begin{array}{c}\text { Assigned } \\
\text { Weight }\end{array}$ \\
\hline $\begin{array}{l}\text { Maths/Arith } \\
\text { Biol/Science }\end{array}$ &, 75 &, 11 & 1,0 &, $1 \%$ & 22 & 2 \\
Other &, 25 &, 89 & 1,0 &, $1 \%$ & -22 & 0 \\
\hline
\end{tabular}

DO YOU OWN A CAMERA?

\begin{tabular}{|l|c|c|c|c|c|c|}
\hline Item & $\begin{array}{c}\text { Proportion } \\
\text { High Group }\end{array}$ & $\begin{array}{l}\text { Proportion } \\
\text { Low Group }\end{array}$ & $\begin{array}{l}\text { Omega- } \\
\text { value }\end{array}$ & $\begin{array}{c}\text { Signifi- } \\
\text { cance }\end{array}$ & $\begin{array}{c}\text { Nett- } \\
\text { weight }\end{array}$ & $\begin{array}{c}\text { Assigned } \\
\text { Weight }\end{array}$ \\
\hline Yes &, 38 &, 11 &, 43 &, $1 \%$ & 6 & 2 \\
No &, 62 &, 89 &, 43 &, $1 \%$ & -6 & 0 \\
\hline
\end{tabular}

CAN YOU DRIVE A CAR?

\begin{tabular}{|l|c|c|c|c|c|c|}
\hline Item & $\begin{array}{c}\text { Proportion } \\
\text { High Group }\end{array}$ & $\begin{array}{l}\text { Proportion } \\
\text { Low Group }\end{array}$ & $\begin{array}{l}\text { Omega- } \\
\text { value }\end{array}$ & $\begin{array}{c}\text { Signifi- } \\
\text { cance }\end{array}$ & $\begin{array}{c}\text { Nett- } \\
\text { weight }\end{array}$ & $\begin{array}{c}\text { Assigned } \\
\text { Weight }\end{array}$ \\
\hline Yes &, 79 &, 50 &, 46 &, $1 \%$ & 7 & 2 \\
No &, 21 &, 50 &, 46 &, $1 \%$ & -7 & 0 \\
\hline
\end{tabular}

BO YOU OWN A CAR?

\begin{tabular}{|l|c|c|c|c|c|c|}
\hline Item & $\begin{array}{l}\text { Proportion } \\
\text { High Group }\end{array}$ & $\begin{array}{l}\text { Proportion } \\
\text { Low Group }\end{array}$ & $\begin{array}{l}\text { Omega- } \\
\text { value }\end{array}$ & $\begin{array}{l}\text { Signifi- } \\
\text { cance }\end{array}$ & $\begin{array}{c}\text { Nett- } \\
\text { weight }\end{array}$ & $\begin{array}{c}\text { Assigned } \\
\text { Weight }\end{array}$ \\
\hline Yes &, 26 &, 10 &, 31 &, $1 \%$ & 7 & $:$ \\
No &, 74 &, 90 &, 31 &, $1 \%$ & -7 & 0 \\
\hline
\end{tabular}

DO YOU HAVE ANY TOOLS AT HOME?

\begin{tabular}{|l|c|c|c|c|c|c|}
\hline Item & $\begin{array}{l}\text { Proportion } \\
\text { High Group }\end{array}$ & $\begin{array}{l}\text { Proportion } \\
\text { Low Group }\end{array}$ & $\begin{array}{l}\text { Omega- } \\
\text { value }\end{array}$ & $\begin{array}{c}\text { Signifi- } \\
\text { cance }\end{array}$ & $\begin{array}{c}\text { Nett- } \\
\text { weight }\end{array}$ & $\begin{array}{c}\text { Assigned } \\
\text { Weight }\end{array}$ \\
\hline Yes &, 55 &, 71 &, 25 &, $1 \%$ & -4 & 0 \\
No &, 45 &, 29 &, 25 &, $1 \%$ & 4 & 2 \\
\hline
\end{tabular}


The biographical inventory yielded a $r=, 49$ with the criterion.

\section{The relationship between subtests, criterion and total scores}

The vast amount of statistical data obtained for the test necessitated the use of a computer to determine the relationships between subtests, criterion and total scores. The results of this computation are presented in the matrix below.

TABLE 2

THE RELATIONSHIPS BETWEEN SUBTESTS, CRITERION

AND TOTAL SCORES

\begin{tabular}{|c|c|c|c|c|c|c|c|c|c|c|}
\hline & 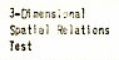 & 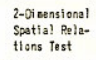 & 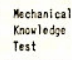 & $\begin{array}{l}\text { Pechanical } \\
\text { PProblea- } \\
\text { solving Tost }\end{array}$ & 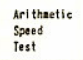 & $\begin{array}{l}\text { Africkans } \\
\text { Vocatulary } \\
\text { Test }\end{array}$ & $\begin{array}{l}\text { Enoll sh } \\
\text { Yocabulary } \\
\text { Test }\end{array}$ & $\begin{array}{l}\text { Sliographical } \\
\text { inventory }\end{array}$ & $\begin{array}{l}\text { Total } \\
\text { Scores }\end{array}$ & corterion \\
\hline & 1 & 2 & 3 & 4 & 5 & 6 & ? & 8 & 9 & 10 \\
\hline 1 & & 0,555 & $0, \mathrm{BL}_{2}$ & 0,57 & 0,45 & 0,214 & 0,477 & $0,4 \leqslant 3$ & 0,715 & 0,119 \\
\hline 2 & & & 0,651 & 0,666 & 0,30 & $0, \times 9$ & 0.535 & $0,4 \%$ & 0,655 & 0,693 \\
\hline 3 & & & & 0,114 & 0,560 & 0,511 & 0,655 & 0,463 & 0,728 & 0,283 \\
\hline 4 & & & & & 0,515 & 0,42 & 0,507 & $0,3 x 1$ & 0,678 & 0,683 \\
\hline 5 & & & & & & 0,176 & 0,451 & 0,470 & 0,650 & 0,619 \\
\hline 6 & & & & & & & 0,499 & 0,126 & 0,433 & 0,554 \\
\hline ? & & & & & & & & 0,35 & 0,94 & 0,582 \\
\hline 8 & & & & & & & & & 0,417 & 0,400 \\
\hline 9 & & & & & & & & & & 0,788 \\
\hline
\end{tabular}

It will be noted from the matrix that all the tests correlated highly with the total score as well as with the criterion of success.

By using the information in the matrix, it was possible to compute a multiple $\mathrm{R}$ for the battery. Jenkin's (1952, p.316) method was used for this purpose and the results obtained appear in table 3.

\section{$\underline{\text { TABLE } 3}$}

\section{MULTIPLE R}

\begin{tabular}{|c|l|l|l|}
\hline $\mathrm{R}$ & \multicolumn{2}{|c|}{} & \\
\hline, 739 & $\begin{array}{l}\text { Mechanical } \\
\text { Knowledge Test }\end{array}$ & & \\
, 805 & $\begin{array}{l}\text { Mechanical } \\
\text { Knowledge Test }\end{array}$ & $\begin{array}{c}\text { 3- Dimensional spatial } \\
\text { Relations Test }\end{array}$ & \\
& $\begin{array}{l}\text { Mechanical } \\
\text { Knowledge Test }\end{array}$ & $\begin{array}{c}\text { 3- Dimensional spatial } \\
\text { Relations Test }\end{array}$ & $\begin{array}{c}\text { 2-Dimensional spatial } \\
\text { Relations Test }\end{array}$ \\
\hline
\end{tabular}


It is evident from table 3 that a high multiple $\mathrm{R}$ was obtained. Also interesting is that only those tests mentioned in the table, made any contribution to this multiple R. It can therefore be assumed that by using only these three tests in a battery, the same predictive validity should be obtained as when the whole battery of eight tests is used. The decision was made however not to decrease the number of subtests into one long test and therefore no further calculations, such as shrinkage were undertaken with the multiple R.

\section{Internal consistency}

The internal consistency of each subtest was computed by making use of the KuderRichardson Formula no. 20. The results obtained are presented in table 4.

\section{TABLE 4}

INTERNAL CONSISTENCY

\begin{tabular}{|c|c|c|c|}
\hline Ho & Tests & ${ }^{\mathrm{KR}} \mathrm{R}_{20}$ & $S_{e}$ \\
\hline 1. & $\begin{array}{c}\text { 3- Disensional spatial relations } \\
\text { Test }\end{array}$ & 91 & 1,60 \\
\hline 2. & $\begin{array}{c}2-\text { Oimensional spatial relations } \\
\text { Test }\end{array}$ & . & 1,91 \\
\hline 3. & Mechanical knowledge Test &, 86 & 2,00 \\
\hline 4. & Mechanical problen Test &, 80 & 1,97 \\
\hline 5. & Ari thmotic speed test & 849 & 1,90 \\
\hline 6. & Afrikaans vocabulary test & 97 &, 64 \\
\hline 7. & English vocabulary test & ,863 & 1,76 \\
\hline 8. & Test Battery & 96 & 5,40 \\
\hline
\end{tabular}

The $\mathrm{KR}_{20}$ of the arithmetic speed test was found under power test conditions. It is evident that every subtest obtained high reliabilities. The battery as a whole also appears to be very reliable and a $r=, 96$ was obtained. 


\section{Language medium}

Although the test and multiple-choice items were presented in English and three African languages, not one testee made use of the African languages. It was concluded that testees at this level of education prefer to take tests in English.

\section{The final test}

The final test was constructed on the basis of the statistics obtained from the analysis of the preliminary test battery and the following decisions were made:

\section{Subtests}

Subtests were selected in terms of the relationships between subtests, criterion and total scores as well as the results of the multiple $\mathrm{R}$ computation. It appeared from the results that the Afrikaans vocabulary test was not valid and was therefore not included in the final test. The multiple $\mathrm{R}$ indicated that only three tests, mechanical knowledge, and two- and threedimensional spatial relations, made any contribution toward predicting the criterion. It was decided, nevertheless, to include not only these three tests, but also the remaining three. The reason for this was to increase the number of test items and thereby improve the reliability of the test. The biographical inventory was also included, mainly for two reasons. Firstly, unlike the other subtests, the biographical inventory predicted the whole criterion, i.e. mechanical ability, and not only a subability of mechanical ability as the other subtests. Secondly, it was decided to use the biographical inventory as a buffer test. In other words a test that is completed first in the test series, but not scored. The purpose of a buffer test is to acquaint testees with the type of test content as well as to help them overcome their initial fear and unease. It is considered good practice to include buffer tests when testing the African population.

With the foregoing as a basis, it was decided to include the following subtests in the final test.

\footnotetext{
Biographical inventory

Mechanical knowledge test

Three-dimensional spatial relations test

Arithmetic speed test

English vocabulary test

Two-dimensional spatial relations test
} 
Mechanical problem solving test

As can be seen, an attempt was made to alternate verbal and nonverbal tests and at the same time arranging them from easy to difficult.

\section{Test items}

Test items were selected on three important factors. Firstly, the item-test and itemcriterion correlations were used to select only the most valid items in terms of the criterion and internal consistency. Only tetrachoric correlations larger than 0,50 and significant at the 1 $\%$ level, were used. Secondly, items were chosen in terms of item difficulty. Only items with a difficulty value around ,50 were included. The only exception was the arithmetic speed test where items with a difficulty value of ,95 or larger were used. The reason for this was the fact that speed is measured in this test and not the ability to do arithmetic. The third factor that was considered while choosing items was the practical use of certain items. It was decided to combine the subtests of the previous battery into one single final test and therefore it was necessary to decrease the number of items. Only those items that were valid, but also practical in the sense that they consumed less space were included. Face validity was also taken into account while decreasing the number of items.

\section{General considerations}

Notwithstanding the decisions already mentioned, many other changes were made and the final test consisted of the best items, arranged in the best way. It should be mentioned that all the multiple-choice type items were improved on the basis of the distractor analysis. The final test was presented in English only and the sub-part covering Afrikaans vocabulary was excluded. All through the application of the different forms of the test battery careful note was made of the times required to complete each sub-part of the test. The time restrictions for the final test were calculated on the basis of this information.

\section{Application of the final test}

The final test was applied to 100 industrial workers who were engaged in mechanical type jobs as well as to 100 Black male matriculants. The purpose of this application was to determine the reliability of the test as well as to prepare norm tables for the further use of the test. 


\section{Reliability of the final test}

An odd-even split was made of the final test and there-after scored. The two resulting distributions were correlated using the ordinary Pearson's product-moment technique. A reliability of $\mathrm{r}=0,951$ was obtained. A standard error of measurement was also computed and was found to be 4,85 .

\section{Computation of normalised standard scores}

The results obtained from the application of the final test was used to compile two sets of standard scores which can be used for the two population samples used for computing them. The method employed consisted of the use of normal probability paper and the computation of norms by using cumulative proportions. The norm tables for the two groups appear in table 5.

\section{TABLE 5}

\section{NORM TABLES FOR TWO GROUPS}

A. Stanines (100 - Black Matriculants)

\begin{tabular}{|cc|}
\hline Raw Scores & Stanines \\
\hline $84-114$ & 9 \\
$78-83$ & 8 \\
$72-77$ & 7 \\
$64-71$ & 6 \\
$56-63$ & 5 \\
$49-55$ & 4 \\
$43-48$ & 3 \\
$37-42$ & 2 \\
$0-36$ & 1 \\
\hline
\end{tabular}

B. Staines (100 Factory workers)

\begin{tabular}{|cc|}
\hline Raw Scores & Stanines \\
\hline $82-114$ & 9 \\
$70-81$ & 8 \\
$61-69$ & 7 \\
$50-60$ & 6 \\
$40-49$ & 5 \\
$31-39$ & 4 \\
$23-30$ & 3 \\
$14-22$ & 2 \\
$0-13$ & 1 \\
\hline
\end{tabular}


It will be noted from the tables that the scores for the two groups differ considerably. It appears that industrial workers scored less well than the school group.

\section{The final test manual}

A final test manual was constructed and contains three types of information:

- Information that will enable prospective users of the test to determine whether the test meets their requirements.

- Information that will enable users to apply and score the test in a uniform way.

- $\quad$ Information that will assist the user in interpreting test scores.

The information contained in the manual is comprehensive and is based on all the facts regarding the test as determined through the various applications thereof.

\section{CONCLUSIONS}

Although the study was conducted under difficult conditions which prevailed as a result of riots and the resulting reluctance of companies to participate in research involving Black workers it can be stated that all the objectives that were set, were attained.

The test itself is the result of long and intensive research, but it must be added that much more needs to be done before the test can be regarded as being complete. It is suggested that more validation studies, especially on different job categories be undertaken to find further fields of application for the test. Improvement of the drawings is envisaged together with improved printing.

\section{SUMMARY}

The tremendous industrial growth of South Africa has created shortages of technically qualified persons. The White population, who traditionally filled these posts, is no longer able to satisfy the demand. The Black workers in South Africa are therefore being trained to a greater extent to fill such posts. A need for an objective selection device for selecting these workers arose and this study is an attempt to provide such a device. A mechanical ability test was constructed and the preliminary standardisation was successfully undertaken. 


\section{APPENDIX A \\ TABLE $A-1$}

\section{ITEM ANALYSIS - 3 - D TEST}

\begin{tabular}{|c|c|c|c|c|c|}
\hline Itean no & $\mathrm{r}_{\mathrm{ic}}$ & Significance & $\begin{array}{l}\text { Difficulty - } \\
\text { value }\end{array}$ & $r_{i t}$ & Si gnificance \\
\hline 1. & ,61 &, $1 \%$ &, 83 &, 80 &, $1 \%$ \\
\hline 2. &, 50 &, $1 \%$ & ,64 & 68 &, $1 \%$ \\
\hline 3. &, 45 &, $1 \%$ & ,68 &, 70 & $; 1 \%$ \\
\hline 4. &, 45 &, $1 \%$ & ,66 &, 70 &, $1 \%$ \\
\hline 5. & ,76 &, $1 \%$ & 76 &, 90 & $1 \%$ \\
\hline 6. & 89 & $1 \%$ &, 60 &, 95 & $1 \%$ \\
\hline 7. &, 70 &, $1 \%$ & 65 &, 63 &, $1 \%$ \\
\hline 8. &, 95 & $1 \%$ &, 55 &, 95 &, $1 \%$ \\
\hline 9. & 82 &, $1 \%$ &, 64 &, 92 &, $1 \%$ \\
\hline 10. & 89 &, $1 \%$ &, 44 &, 95 &, $1 \%$ \\
\hline 11. &,- 50 & - &, 40 &,- 50 & - \\
\hline 12. &, 28 &, $1 \%$ &, 29 & ,92 &, $1 \%$ \\
\hline 13. &, 70 &, $1 \%$ & .53 & 90 &, $1 \%$ \\
\hline 14. & 0 & - & 0 & 0 & - \\
\hline 15. &, 70 &, $1 \%$ &, 50 & ,81 &, $1 \%$ \\
\hline 16. &, 70 &, $1 \%$ &, 50 &, 82 &, $1 \%$ \\
\hline 17. & 90 & $1 \%$ &, 19 & ,92 &, $1 \%$ \\
\hline 18. & 93 & $1 \%$ &, 33 &, 95 & ,18 \\
\hline 19. &, 79 & $1 \%$ &, 54 &, 80 & $1 \%$ \\
\hline 20. & 0 & - & 0 & 0 & - \\
\hline 21. & 93 &, $1 \%$ & .55 & 95 &, $1 \%$ \\
\hline 22. &, 82 &, $1 \%$ &, 71 &, 88 &, $2 \%$ \\
\hline
\end{tabular}


APPENDIX A

TABLE A -2

ITEM ANALYSIS - 2 - D TEST

\begin{tabular}{|c|c|c|c|c|c|}
\hline No & $r_{i c}$ & Significance & $\begin{array}{l}\text { Difficulty - } \\
\text { value }\end{array}$ & $r_{\text {it }}$ & Significance \\
\hline 1. & ,78 &, $1 \%$ & ,69 & 86 &, $1 \%$ \\
\hline 2. &, 55 &, $1 \%$ & 83 & ,65 &, $1 \%$ \\
\hline 3. & .65 &, $1 \%$ &, 66 &, 77 &, $1 \%$ \\
\hline 4. &, 74 & ,1\% &, 74 & 81 &, $1 \%$ \\
\hline 5. &, 60 & , 1\% &, 73 & 91 &, $1 \%$ \\
\hline 6. &, 70 & , 1\% & ,63 & 91 &, $1 \%$ \\
\hline 7. &, 51 &, $1 \%$ & ,65 & ,60 &, $1 \%$ \\
\hline 8. & 0 & - & 0 & 0 & - \\
\hline 9. &, 60 &, $1 \%$ & ,68 &, 80 &, $1 \%$ \\
\hline 10. &, 73 &, $1 \%$ &, 55 &, 95 &, $1 \%$ \\
\hline 11. &, 80 &, $1 \%$ &, 49 &, 87 &, $1 \%$ \\
\hline 12. &, 78 &, $1 \%$ & .69 & 80 &, $1 \%$ \\
\hline 13. &, 75 &, $1 \%$ &, 60 &, 94 & ,1\% \\
\hline 14. &, 59 &, $1 \%$ & ,39 & ,84 &, $1 \%$ \\
\hline 15. & ,49 &, $1 \%$ & ,66 &, 77 &, $1 \%$ \\
\hline 16. &, 59 &, $1 \%$ &, 51 &, 84 &, $1 \%$ \\
\hline 17. &, 65 &, $1 \%$ & ,65 &, 69 & $1 \%$ \\
\hline 18. &, 82 &, $1 \%$ &, 44 &, 95 &, $1 \%$ \\
\hline 19. &, 71 &, $1 \%$ &, 56 &, 78 &, $1 \%$ \\
\hline 20. &, 72 & $.1 \%$ &, 80 &, 65 &, $1 \%$ \\
\hline 21. &, 92 &, $1 \%$ &, 58 &, 93 &, $1 \%$ \\
\hline 22. & .55 & ,1\% &, 44 &, 79 &, $1 \%$ \\
\hline 23. & 91 & ,1\% & .53 & 82 &, $1 \%$ \\
\hline 24. & , 61 &, $1 \%$ &, 46 & ,60 &, $1 \%$ \\
\hline 25. & 90 &, $1 \%$ &, 34 & 90 & , $1 \%$ \\
\hline
\end{tabular}




\section{APPENDIX A}

TABLE A - 3

ITEM ANALYSIS - MECHANICAL KNOWLEDGE TEST

\begin{tabular}{|c|c|c|c|c|c|}
\hline Ho & $\mathrm{r}_{\mathrm{ic}}$ & Significance & $\begin{array}{l}\text { Difficulty- } \\
\text { value }\end{array}$ & $r_{i t}$ & Significance \\
\hline 1. &, 60 & $1 \%$ &, 15 &, 41 &, $1 \%$ \\
\hline 2. & 20 &, $1 \%$ &, 81 &, 55 &, $1 \%$ \\
\hline 3. &, 58 &, $1 \%$ &, 49 & ,68 & $1 \%$ \\
\hline 4. &, 52 &, $1 \%$ & ,23 & ,71 &, $1 \%$ \\
\hline 5. &, 71 & $1 \%$ &, 67 & ,25 &, $1 \%$ \\
\hline 6. &, 70 & $1 \%$ &, 45 &, 51 & $1 \%$ \\
\hline 7. & ,81 &, $1 \%$ & .73 & , 41 & $1 \%$ \\
\hline 8. &, 74 &, $1 \%$ & ,44 & ,69 & $1 \%$ \\
\hline 9. &, 38 & , 1\% & ,75 & , 32 & , 1\% \\
\hline 10. &, 07 & $20 \%$ &, 36 & ,60 &, $1 \%$ \\
\hline 11. &,- 29 & - &, 69 &, 43 & $1 \%$ \\
\hline 12. & 159 & $1 \%$ & 89 &, 55 & ,1\% \\
\hline 13. &, 24 &, $1 \%$ & 89 & ,50 & , 1\% \\
\hline 14. &,- 21 & - & 88 &,- 18 & - \\
\hline 15. &, 60 & , $1 \%$ & 89 & ,70 & , 18 \\
\hline 16. &, 50 & $1 \%$ & ,95 &, 50 & $1 \%$ \\
\hline 17. & ,70 & , $1 \%$ & 89 & ,73 &, $1 \%$ \\
\hline 18. & ,40 & , 1\% & ,63 & ,82 & , 10 \\
\hline 19. & ,61 & , $1 \%$ &, 40 & 90 & , $1 \%$ \\
\hline 20. &, 45 &, $1 \%$ &, 83 &,- 37 &, $1 \%$ \\
\hline 21. & 0 & - & 0 & 0 & - \\
\hline 22. & 95 & , $1 \%$ & , 33 & .79 & , $1 \%$ \\
\hline 23. & ,80 & , 1\% & ,83 & ,62 & , 1\% \\
\hline 24. & ,82 & , 19\% & , 80 & 80 & , 1\% \\
\hline 25. &, 51 &, $1 \%$ & ,65 &, 50 &, $1 \%$ \\
\hline 26. &, 95 &, $1 \%$ & , 48 &,- 22 & - \\
\hline 27. &, 95 & , $1 \%$ & ,6? &, 56 &, $1 \%$ \\
\hline 28. &, 04 & $=$ & ,25 & ,21 & $1 \%$ \\
\hline 29. & ,62 &, $1 \%$ &, 95 &, 30 &, $1 \%$ \\
\hline 30. &, 85 & $1 \%$ & ,83 & ,80 & ,18 \\
\hline
\end{tabular}


APPENDIX A

TABLE A - 4

ITEM ANALYSIS - MECHANICAL ABILITY TEST

\begin{tabular}{|c|c|c|c|c|c|}
\hline Mo & $r_{i c}$ & Significance & $\begin{array}{l}\text { Oifficulty- } \\
\text { value }\end{array}$ & $r_{i t}$ & Significance \\
\hline 1. &, 95 &, $1 \%$ &, 34 &, 76 &, $1 \%$ \\
\hline 2. &, 70 &, $1 \%$ &, 70 &, 17 & $1 \%$ \\
\hline 3. & 90 &, $1 \%$ &, 46 & ,95 &, $2 \%$ \\
\hline 4. &, 70 &, $1 \%$ &, 24 & ,81 &, $1 \%$ \\
\hline 5. &, 50 &, $1 \%$ &, 90 & ,60 &, $1 \%$ \\
\hline 6. &, 70 & $.1 \%$ & 0 & 80 & $1 \%$ \\
\hline 7. & ,68 &, $1 \%$ &, 22 & 90 & $1 \%$ \\
\hline 8. &, 45 &, $1 \%$ & 18 &, 90 &, $1 \%$ \\
\hline 9. &, 78 &, $1 \%$ &, 82 &,- 26 & - \\
\hline 10. & ,66 &, $1 \%$ & ,28 &, 58 &, $1 \%$ \\
\hline 11. &,- 01 & - &, 52 &, 56 &, $1 \%$ \\
\hline 12. & 85 &, $1 \%$ &, 16 &, 90 &, $1 \%$ \\
\hline 13. &.,- 55 & - &, 33 &,- 26 & - \\
\hline 14. &, 20 &, $1 \%$ &, 34 &, 48 &, $1 \%$ \\
\hline 15. &,- 25 & - &, 24 &,- 31 & - \\
\hline 16. & 93 &, $1 \%$ & .56 & 91 &, $1 \%$ \\
\hline 17. &,- 01 & - & ,60 &,- 06 & - \\
\hline 18. &, 28 &, $1 \%$ &, 42 &, 27 &, $1 \%$ \\
\hline 19. &, 65 &, $1 \%$ & 0 & 0 & - \\
\hline 20. &, 80 & $1 \%$ & ,26 &, 95 & $1 \%$ \\
\hline 21. &,- 10 & - & ,68 &, 51 &, $1 \%$ \\
\hline 22. & .84 &, $1 \%$ &, 54 &, 69 &, $1 \%$ \\
\hline 23. & ,65 & ,1\% &, 06 &, 60 & $1 \%$ \\
\hline 24. & .65 &, $1 \%$ &, 08 & .70 &, $1 \%$ \\
\hline 25. & 95 &, $1 \%$ & ,34 & .95 &, $1 \%$ \\
\hline 26. & .72 &, $1 \%$ &, 51 & 87 &, $1 \%$ \\
\hline 27. & ,60 &, $1 \%$ & , 44 & 90 & , 1\% \\
\hline 28. & 0 & - & 0 & 0 & - \\
\hline 29. & 0 & - & 0 & 0 & - \\
\hline
\end{tabular}


APPENDIX A

TABLE $\quad A-5$

ITEM ANALYSIS - ARITHMETIC SPEED TEST

\begin{tabular}{|c|c|c|c|c|c|}
\hline No & $\mathrm{r}_{\mathrm{ic}}$ & Significance & $\begin{array}{l}\text { Difficulty- } \\
\text { value }\end{array}$ & $r_{i t}$ & Significance \\
\hline 1. & 0 & - & 89 & ,01 & - \\
\hline 2. & ,48 &, $1 \%$ & ,62 & ,6? & , 1\% \\
\hline 3. & ,20 &, $1 \%$ & ,86 & ,29 & ,1\% \\
\hline 4. &, 63 &, $1 \%$ & , & ,80 &, $1 \%$ \\
\hline 5. & , 49 &, $1 \%$ & ,59 & ,72 &, $2 \%$ \\
\hline 6. &, 50 &, $1 \%$ & ,83 & , 50 & $1 \%$ \\
\hline 7. &, 20 & $1 \%$ &, 85 & 65 &, $1 \%$ \\
\hline 8. & ,60 & , 1\% & ,89 & ,65 & $1 \%$ \\
\hline 9. &, 53 & $1 \%$ & ,70 & ,79 &, $1 \%$ \\
\hline 10. &, 79 & , 1\% & ,73 &, 43 & , $1 \%$ \\
\hline 11. &, 34 &, $1 \%$ & ,75 & -.04 & - \\
\hline 12. & ,3c &, $1 \%$ & ,64 & ,65 &, $1 \%$ \\
\hline 13. & ,64 &, $1 \%$ & , 25 & ,22 & , $1 \%$ \\
\hline 14. &, 75 & ,1\% & ,75 & 80 & , 1\% \\
\hline 15. &, 74 &, $1 \%$ & ,51 & .55 &, $1 \%$ \\
\hline 16. &, 33 &, $1 \%$ & 66 & ,75 & $1 \%$ \\
\hline 17. &, 58 &, $1 \%$ &, 55 & ,69 &, $1 \%$ \\
\hline 18. & ,20 &, $1 \%$ &, 45 & ,51 & , 1\% \\
\hline 19. & .55 & $1 \%$ & ,25 &, 74 & , 1\% \\
\hline 20. &, 50 &, $1 \%$ &, 23 & ,64 & $1 \%$ \\
\hline 2]. &, 26 &, $1 \%$ &, 13 & 80 &, $1 \%$ \\
\hline 22. &, 46 & , 1\% &, 26 &, 73 & , $1 \%$ \\
\hline 23. & ,20 &, $1 \%$ & ,18 & .40 & , 1\% \\
\hline 24. &, 10 & $10 \%$ &, 37 & ,65 &, $1 \%$ \\
\hline 25. &, 10 & $10 \%$ & ,23 & , 80 &, $1 \%$ \\
\hline
\end{tabular}


APPENDIX A

TABLE A -6

ITEM ANALYSIS - AFRIKAANS VOCABULARY TEST

\begin{tabular}{|c|c|c|c|c|c|}
\hline No & $r_{i c}$ & Significance & $\begin{array}{l}\text { Difficulty- } \\
\text { value }\end{array}$ & $r_{1 t}$ & Significance \\
\hline 1. &, 29 & , 1\% & 09 &, 60 &, $1 \%$ \\
\hline 2. &, 60 &, $1 \%$ &, 06 & ,70 &, $1 \%$ \\
\hline 3. & 0 & - & 15 & 80 &, $1 \%$ \\
\hline 4. &, 60 & $1 \%$ &, 04 &, 60 &, $1 \%$ \\
\hline 5. & .47 &, $1 \%$ &, 31 & 90 &, $1 \%$ \\
\hline 6. &, 20 & ,1\% &, 15 &, 85 & ,18 \\
\hline 7. &, 50 & $1 \%$ &, 53 & 82 &, $1 \%$ \\
\hline 8. &, 70 & $1 \%$ & ,11 &,- 09 & - \\
\hline 9. & 0 & - & 0 &, 60 &, $1 \%$ \\
\hline 10. &,- 10 & - &, 08 & ,75 &, $1 \%$ \\
\hline 11. &, 71 &, $1 \%$ &, 23 &, 10 & $10 \%$ \\
\hline 12. &, 77 &, $1 \%$ & .48 &, 59 &, $1 \%$ \\
\hline 13. & 0 & - & 0 & 0 & - \\
\hline 14. &.,- 50 & - &, 06 & ,75 &, $1 \%$ \\
\hline 15. & 0 & - & 0 & 0 & - \\
\hline 16. &, 80 & $1 \%$ & 10 &, 65 &, $1 \%$ \\
\hline 17. &,- 09 & - & 10 &, 70 &, $1 \%$ \\
\hline 18. & 0 & - & 0 & 0 & - \\
\hline 19. & 81 & , $1 \%$ & ,26 & .85 &, $1 \%$ \\
\hline 20. & 0 & - & 0 & 0 & - \\
\hline
\end{tabular}


APPENDIX A

TABLE A -7

ITEM ANALYSIS - ENGLISH VOCABULARY TEST

\begin{tabular}{|c|c|c|c|c|c|}
\hline Ho & $r_{i c}$ & Significance & $\begin{array}{l}\text { Oifficulty- } \\
\text { value }\end{array}$ & $r_{i t}$ & Significance \\
\hline 1. & ,89 & , 1\% &, 38 &, 69 &, $1 \%$ \\
\hline 2. &, 95 & $1 \%$ &, 35 &, 75 & , 1\% \\
\hline 3. & 0 & - & 0 & 0 & - \\
\hline 4. &, 95 & $1 \%$ &, 55 &, 90 &, $1 \%$ \\
\hline 5. & 90 & $1 \%$ &, 49 &, 93 &, $1 \%$ \\
\hline 6. &, 95 &, $1 \%$ & ,61 &, 90 &, $1 \%$ \\
\hline 7. & 80 &, $1 \%$ & 10 &, 70 &, $1 \%$ \\
\hline 8. & ,60 & , $1 \%$ &, 20 &, 66 &, $1 \%$ \\
\hline 9. &, 95 & , 1\% &, 56 &, 95 &, $1 \%$ \\
\hline 10. &, 95 &, $1 \%$ & , 49 &, 95 &, $1 \%$ \\
\hline 11. & 95 &, $1 \%$ &, 40 &, 72 &, $1 \%$ \\
\hline 12. &, 80 &, $1 \%$ &, 19 &, 71 &, $1 \%$ \\
\hline 13. & ;91 & , $1 \%$ & ,39 &, 93 &, $1 \%$ \\
\hline 14. & 0 & - & ,01 &, 25 & - \\
\hline 15. & 91 &, $1 \%$ &, 43 &, 95 &, $1 \%$ \\
\hline 16. &, 69 &, $1 \%$ &, 40 & .50 &, $1 \%$ \\
\hline 17. &, 88 &, $1 \%$ &, 56 &, 80 &, $1 \%$ \\
\hline 18. &, 90 & , 1\% &, 50 &, 76 &, 18 \\
\hline 19. &, 95 & 18 &, 56 & 90 &, $1 \%$ \\
\hline 20. & 95 & 18 & .55 & 95 &, $1 \%$ \\
\hline
\end{tabular}




\section{APPENDIX B \\ TABLE $\quad B-1$}

DISTRACTOR ANALYSIS - 3 - D TEST

\begin{tabular}{|c|c|c|c|c|c|c|c|c|c|c|c|c|c|c|c|c|c|c|c|c|c|c|c|c|c|}
\hline 110 & \multicolumn{5}{|c|}{ Chaice 1} & \multicolumn{5}{|c|}{ Chotec 2} & \multicolumn{5}{|c|}{ Choles 3} & \multicolumn{5}{|c|}{ Cholce 4} & \multicolumn{5}{|c|}{ Soleo 5} \\
\hline & PI & $\mathrm{PH}$ & PL & 0 & 5 & $\mathrm{PI}$ & PII & $\mathrm{Pl}$ & 0 & $s$ & $\mathrm{PT}$ & PMI & $\mathrm{Pl}$ & 0 & s & PI & PII] & $n$ & 0 & $s$ & PT & p时 & $n$ & 0 & 3 \\
\hline 1 &, 95 & 1 & 18 & 1,45 & .1 & 15 & 1 & 8 &, 27 & 1 & 5,5 & 3 & 8 & & 20 & & & & & & 6,5 & 0 & 13 & .53 &, 1 \\
\hline 2 & 9 & 0 & 18 &, 61 &, 1 & & & & & & 17 & 10 & 24 & , 2 & 1 & 6 & 4 & 8 &, 11 & - & 0 & 0 & 0 & 0 & - \\
\hline 3 & 3,5 & 0 & 7 &, 40 &, 1 & 10 & 6 & 14 & .20 & 5 & 16 & 2 & 14 & .34 &, 1 & & & & & & 9 & 4 & 14 & .25 & 2 \\
\hline 4 & & & & & & 4 & 1 & 7 &, 27 & 1 & 65 & 4 & 9 &, 13 & 20 & 65 & 1 & 12 &, 36 &, 1 & 8 & 6 & 10 &, 10 & - \\
\hline 5 & 1,5 & 0 & 3 & ,29 & 1 & 17 & 3 & $\pi 1$ & 89 & , 1| & $t$ & 0 & 8 & , 41 & , 1 & & & & & & 35 & 3 & 4 &, 09 & - \\
\hline 6 & 19 & 3 & 35 & .65 &, 1 & 10 & 2 & 18 & ,4] &, 1 & 3 & 0 & 6 & .57 &, 1 & 45 & 4 & 5 & .03 & - & & & & & \\
\hline 7 & .5 & 0 & 1 &, 15 & 20 & 16,5 & 1 & .26 & , \# & , 1 & 10,5 & 3 & 18 &, 30 &, 1 & & & & & & 2,5 & 1 & 4 &, 1 & - \\
\hline 8 & 2,5 & 1 & 4 &, 10 & -1 & & & & & & 80 & 5 & 5 & 87 &, 1 & 3 & 0 & 6 &, 37 & 1 & 0 & 0 & 0 & 0 & - \\
\hline 9 & 7 & 2 & 12 &, 38 & 1 & 6,5 & 0 & 13 & .53 & , 1 & 3,5 & 1 & 6 &, 20 & 5 & & & & & & 16,5 & 4 & $\approx$ & , &, 1 \\
\hline 10 & & & & & & 7,5 & 2 & 13 & 31 & 1 & 7,5 & 1 & 14 & , & 1 & 15,5 & 12 & 19 & & 20 & 9,5 & 0 & 19 &, 64 &, 1 \\
\hline 11 & 9 & 3 & 15 & .31 & 1 & 50,5 & 72 & 29 & .62 &, 1 & & & & & & 7,5 & 5 & 10 & & 20 & 9 & 2 & 16 & , ㅋ &, 1 \\
\hline 12 & 27 & 10 & 44 & .57 &, 1 & 2 & 1 & 3 &, 11 & - & 32 & 43 & n &, 34 &, 1 & & & & & & 1,5 & 0 & 3 & 29 & 1 \\
\hline 13 &, 5 & 1 & 0 &, 15 & 20 & 13,5 & 9 & 18 & |21 & 5 & & & & & & 10 & 5 & 15 &, 25 & 2 & 12,5 & 1 & 24 &, 98 &, 1 \\
\hline 14 & 18,5 & 3 & 36 & ,63 & 1 & 36,5 & 55 & 18 & .57 &, 1 & 10,5 & 4 & 17 & ,31 & 1 & 32 & 37 & 27 & 16 & 20 & & & & & \\
\hline 15 & 25,5 & 6 & 45 & .68 &, 11 & 1,5 & 1 & 2 &, 09 & - & 5.5 & 7 & 4 &, 10 & - & & & & & & 7 & 11 & 3 & .26 & 1 \\
\hline 16 & 7,5 & 2 & 13 &, 31 & 1 & 10 & 7 & 13 &, 132 & 20 & 2,5 & 0 & 5 & ,34 & , & $n, 5$ & 14 & n &, 30 & 1 & & & & & \\
\hline 17 & 21 & 2 & 10 & .75 & , 1 & $x, 5$ & 50 & 19 & .59 &, 1 . & & & & & & 7 & 4 & 10 & & 20 & 3,5 & 0 & 7 & , &, 1 \\
\hline 18 & 15,5 & 14 & 17 &, 07 & -1 & 20 & 4 & 36 &, 02 & .1月 & 7,5 & 9 & 6 & $\infty$ & - & 1 & 0 & 1 & .15 & 20 & & & & & \\
\hline 19 & 4 & 6 & 2 & .26 & 1 & & & & & & 1,5 & 0 & 3 & 29 & 1 & 4 & 1 & 7 &, 27 & 1 & 21 & 2 & 10 &, 75 & 1 \\
\hline$x$ & 42,5 & 74 & 13 & .96 & 1 & & & & & & 10,5 & 3 & 18 & , 30 &, 1 & 25 & 19 & n &, 20 & 5 & 12,5 & 2 & 23 &, 501 & 1 \\
\hline 21 & 9,5 & 0 & 19 &, 06 & 1 & 20 & 9 & 31 & , 41 &, 1 & 1,5 & 2 & 1 &, 09 & - & & & & & & 6 & 3 & 5 & .07 & - \\
\hline$n$ & 2,5 & 5 & 0 & 1,36 & 11 & 16,5 & 2 & 31 &, 63 &, 1 & & 1 & 1 & 0 & -1 & & & & & & 1,5 & 0 & 3 & & 1 \\
\hline
\end{tabular}

APPENDIX B

TABLE $\quad B-2$

DISTRACTOR ANALYSIS - 2 - D TEST

\begin{tabular}{|c|c|c|c|c|c|c|c|c|c|c|c|c|c|c|c|c|c|c|c|c|c|c|c|c|c|}
\hline No & \multicolumn{5}{|c|}{ Cholce 1} & \multicolumn{5}{|c|}{ Choice 2} & \multicolumn{5}{|c|}{ Cholce 3} & \multicolumn{5}{|c|}{ Cholco 4} & \multicolumn{5}{|c|}{ Chalce 5} \\
\hline & PT & PM & $\mathrm{PL}$ & 0 & $s$ & PT & $\mathrm{PH}$ & $\mathrm{PL}$ & 0 & 5 & PI & $\mathrm{PH}$ & $\mathrm{PL}$ & 0 & 5 & PT & PH] & $P$ & 01 & 5 & PT & $\mathrm{PH}$ & $\mathrm{AL}$ & $D$ & 5 \\
\hline 1 & 1,5 & 2 & 1 &, 04 & - & 4,5 & 0 & 9 & .15 &, 1 & 7 & 3 & 11 &, 26 & 1 & & & & & & 14,5 & 4 & 25 & .46 &, 1 \\
\hline 2 & 2 & 0 & 4 & ,30 & 1 & 5 & 1 & 9 &, 30 & 1 & & & & & & 4 & 4 & 4 & 0 & - & 3,5 & 1 & 6 & 20 & 5 \\
\hline 3 & 4 & 0 & 8 &, 41 & , & 1,5 & 0 & 3 &, 26 & 1 & 8,5 & 4 & 13 &, 26 & 1 & 45 & 1 & 8 &, 29 & 1 & & & & & \\
\hline 4 & 2 & 1 & 3 &, 11 & - & 6,5 & 2 & 11 &, 29 & 1 & & & & & & 5 & 0 & 10 & .48 &, 1 & 10,5 & 3 & 18 & , 8 &, 1 \\
\hline 5 & 1 & 0 & 2 &, 20 & 5 & 2 & 0 & 4 & ,30 & 1 & 15 & 3 & 27 &, 55 &, 1 & & & & & & 4 & 2 & 6 &, $16 \mid x$ & 20 \\
\hline 6 & 45 & 2 & 7 &, 20 & 5 & 4 & 2 & 6 &, 26 & 1 & & & & & & 9,5 & 0 & 19 & ,63 &, 1 & 2,5 & 2. & 13 & 31 & 1 \\
\hline$?$ & 2 & 0 & 6 &, 30 & 1 & 10,5 & 7 & 14 &, 182 & 20 & 15 & 7 & 23 &, 36 &, 1 & & & & & & 2,5 & 0 & 5 & ,31 & 1 \\
\hline 8 & 6,5 & 5 & $B$ &, 10 & - & 59 & 81 & 37 & , 65 &, 1 & & & & & & 13 & 5 & 21 & , 5 &, 1 & 7,5 & 4 & 11 & $, 20: 5$ & 5 \\
\hline 9 & 1,5 & 0 & 3 &, 26 & 1 & 10 & 5 & 15 & 266 & 1 & & & & & & 8 & 4 & 12 &, 26 & 1 & 10,5 & 5. & 16 &, 28 & 1 \\
\hline 10 & 1 & 0 & 2 &, 20 & 5 & 8,5 & 0 & 17 &, 62 &, 1 & 17 & 3 & 31 & ,61 &, 1 & & & & & & 3,5 & 4 & 3 & .04 & - \\
\hline 11 & 2 & 0 & 4 &, 30 & 1 & 7 & 1 & 13 &, 4 &, 1 & 16,5 & 9 & 24 & , 30 & 1 & 6,5 & 1 & 12 &, 36 &, 1 & & & & & \\
\hline 12 & 5 & 1 & 9 & ,30 & 1 & 5 & 0 & 10 &, 50 &, 1 & 8,5 & 3 & 16 &, 36 &, 1 & & & & & & 8,5 & 1 & 16 &, 43 &, 1 \\
\hline 13 & $b$ & 1 & 7 &, 27 & 1. & 5 & 1 & 9 &, 48 &, 1 & 6,5 & 2 & 11 & ,30 & 1 & & & & & & 6 & 3 & 9 &, $18 \times$ & 20 \\
\hline 16 & 2 & 1 & 3 &, 11 & - & 5,5 & 0 & 11 &, 49 & 1 & 13. & 1 & 25 & ,61 & 1 & 17 & 17 & 17 & 0 & - & & 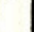 & & & \\
\hline 15 & 3,5 & 2 & 5 & ,15 & 20 & 3,5 & 0 & 7 &, 40 &, 1 & & & & & & 11 & 13 & 9 &, 10 & - & 6,5 & 5 & 8 &, 09 & -1 \\
\hline 16 & 4 & 0 & 9 &, 41 & .1 & 9,5 & 7 & 12 &, 152 & 0 & 7 & 3 & 11 &, 26 & 1 & & & & & & 5 & 2 & 8 &, 20 & 5 \\
\hline 17 & 1 & 0 & 2 & 20 & 5 & 6,5 & 3 & 10 &, 22 & 5 & 6,5 & 4 & 9 &, 18 & 0 & & & & & & 8,5 & 7 & 10 &, 07 & - \\
\hline 18 & & & & & & 14,5 & 9 & 20 &, 24 & 2 & 6 & 4 & 8 &, 13 & $x$ & 6,5 & 2 & 11 &, 28 & 1 & 6,5 & 2 & 11 &, 28 & 1 \\
\hline 19 & .5 & 1 & 0 &, 15 & 20 & 11,5 & 5 & 18 & ,31 & 1 & & & & & & 4,5 & 1 & 8 &, 27 & 1 & 9 & 3 & 15 & ,31 & 1 \\
\hline 20 & 1 & 0 & 2 &, 20 & 5 & 0 & 0 & 0 & 0. & - & & & & & & 3,5 & 0 & 7 & , &, $1 \|$ & 5 & +1 & 6 &, 06 & - \\
\hline 21 & & & & & & 6 & 3 & 9 &, $18 x$ & 0 & 7,5 & 3 & 12 &,$\$ 0$ & 1 & 6,5 & 2 & 11 &, $28^{\circ}$ & 1 & 3. & 2 & 4 &, 10 & - \\
\hline 22 & 6 & 10 & 2 &, 23 & 5 & 5,5 & 4 & 7 &, 11 & - & 5,5 & 3 & 8 &, 20 & 5 & 6 & 1 & 11 & 33 &, 1 & & & & & \\
\hline 23 &, 5 & 1 & 0 &, 15 & 20 & 7,5 & 5 & 10 &, 162 & 0 & & & & & & 6 & 1 & 11 &, 33 &, 1 & 4,5 & 2 & 7 &, $19=$ & 20 \\
\hline 24 & 3,5 & 6 & 1 &, 20 & 5 & 7 & 2 & 12 &, 32 & 1 & 3,5 & 2 & 6 & 19 & 0 & & & & & & nI & 8 & 14 & & 20 \\
\hline 25 & & & & & & 6 & 0 & 8 &, 45 &, 1 & 1,5 & 2 & 1 &, 09 & 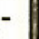 & 6 & 10 & 2 &, 21 & 5 & 16 & 17 & 15 &, 05 & - \\
\hline
\end{tabular}




\author{
APPENDIX B \\ TABLE $\quad B-3$
}

DISTRACTOR ANALYSIS - MECHANICAL KNOWLEDGE TEST

\begin{tabular}{|c|c|c|c|c|c|c|c|c|c|c|c|c|c|c|c|c|c|c|c|c|}
\hline 10 & \multicolumn{5}{|c|}{ Choice I } & \multicolumn{5}{|c|}{ Choice 2} & \multicolumn{5}{|c|}{ Choice } & \multicolumn{5}{|c|}{ Ciraice } \\
\hline & $\mathrm{PI}$ & PH & $p$ & $D$ & 5 & PI. & PY & PL & 0 & 5 & 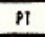 & PH & $P$ & 0 & 5 & 91 & $\mathrm{PH}$ & $\mathrm{Pl}$ & $i$ & $s$ \\
\hline 1 & & 8 & 1 & & 7 & & & & & & $\begin{array}{r}21,5 \\
3,5\end{array}$ & 15 & 28 & .22 & $\begin{array}{l}5 \\
5\end{array}$ & 26 & 34 & 28 & $a$ & - \\
\hline 3 & $\begin{array}{l}12 \\
6,5\end{array}$ & 6 & 1 & , 191 & - & . & 0 & 1 & & 20 & $\begin{array}{l}3,5 \\
5\end{array}$ & 0 & 10 & , & ${ }^{5}, 1$ & 11 & 6 & 16 &, 33 & 5 \\
\hline & ${ }_{1}^{4}$ & $l_{0}^{2}$ & 2 &,${ }_{20}^{.26}$ & $\begin{array}{l}1 \\
5\end{array}$ & $\begin{array}{l}15 \\
22\end{array}$ & $\begin{array}{l}17 \\
11\end{array}$ & $\begin{array}{l}13 \\
33\end{array}$ & . & , & 13 & 4 & 22 &, 00 & , & 2 & ? & & 0 & 1. \\
\hline$\epsilon$ & & & & & & 6 & $?$ & 5 & , 06 & - & 3,5 & 0 & 7 & , & .1 & 6,5 & 0 & 13 & 53 & \\
\hline & 3,5 & 0 & $?$ & 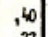 & $\therefore$ & 5 & 0 & 1 & , 15 & 20 & & & & & & $\therefore$ & & $y^{E}$ & 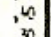 & , 1 \\
\hline 8 & 32 & $\begin{array}{r}25 \\
0\end{array}$ & \$7 & ,22] & 5 & 1,5 & 0 & 3 & 29 & 1 & & & & & & 5,5 & $!$ & 10 & 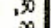 & ? \\
\hline 10 & $47^{4,5}$ & 4 & 45 & , & $2^{\prime \prime}$ & i" & 1 & 3 & ,11 & - & 0 & 0 & 0 & & - & $r_{1}$ & & & & \\
\hline 11 & 3,5 & 1 & 6 &, 20 & 5 & & & & & & 2 & 2 & $?$ & 0 & - & 1 & 0 & 2 & 2 & 5 \\
\hline &, 5 & 0 & 1 &, 15 & 20 & 2,5 & 1 & 4 & , 10 & - & 2,5 & 0 & 5 & ${ }^{34}$ & 1 & & & & & \\
\hline 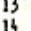 & 1 & 1 & 1 & 0 & - & 4,5 & 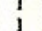 & $\begin{array}{l}2 \\
2\end{array}$ & , & - & & & & & & 1,5 & 0 & $?$ & 29 & 3 \\
\hline & & & & & &, 5 & 1 & 0 & .15 & 20 & 5,5 & 0 & n & .50 &, 1 & .5 & 0 & 1 & ,15 & 20 \\
\hline 1 & , 5 & 0 & i & ,15 & $x_{x}^{\infty}$ & & $\therefore$ & 12 & (49) & נ] & 1 & 0 & 7 & $x$ & & 1,5 & & 3 & $x^{2 x}$ & \\
\hline it & 12,5 & $\begin{array}{c}0 \\
12\end{array}$ & 13 & 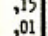 & - & 6 & 1 & 11 & . & , & 1 & 0 & 2 & 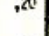 & 3 & 1 & 0 & 2 &, 20 & s \\
\hline & 6,5 & 0 & 13 &, 53 & ,1 & 4,5 & 3 & 6 & , 10 & - & 38 & 14 & 22 & ,15 & 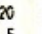 & & 0 & 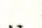 & & \\
\hline & 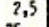 & , & & & 1 & & & & & & 1 & & ? & 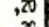 & 5 & 6,5 & $\therefore$ & 13 & . & $\therefore$ \\
\hline${ }_{22}^{21}$ & 75 & ${ }^{85}$ & 65 &, 32 & & 21,5 & 12 & 13 & , 01 & - & $i$ & 1 & 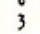 &,$\infty 11$ & - & 4,5 & i] & 6 & "a & $i$ \\
\hline & 3,5 & 0 & $?$ & , & ,1 & 1 & 1 & 5 & 3 & ] & 2 & 1 & 3 &, 11 & - & 6.5 & 5 & & & \\
\hline & 4 & 3 & 6 & & - & 2,5 & 0 & 5 & 以 & , & 10 & $\in$ & 16 & 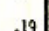 & 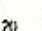 & 4 & $?$ & ¿ & (6) & : \\
\hline & 7 & 7 & 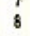 & 011 & - & 5,5 & 1 & 10 & 301 & 1 & & & & & & & 0 & & , x. & 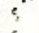 \\
\hline r & 9 , & 2 & 17 & $+\infty$ & .1 & 45,5 & ${ }_{47}^{0}$ & 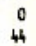 & 0 & $=$ & & $c$ & 1 & 15 & $x$ & $\begin{array}{r}5,5 \\
, 5\end{array}$ & $?_{0}^{2}$ & $\mathrm{i}$ & , 23 & $x_{1}^{5}$ \\
\hline & 0 & 0 & 0 & 0 & - & 3 & 1 & 5 &, 20 & 5 & 2 & 1 & 3 & , 11 & - & & & & & \\
\hline 30 & & 0 & & & 1 & & & & & & & & & & & & 2 & 6 & $\times 1$ & \\
\hline
\end{tabular}

\title{
APPENDIX B \\ TABLE $\quad B-4$
}

DISTRACTOR ANALYSIS - ARITHMETIC SPEED TEST

\begin{tabular}{|c|c|c|c|c|c|c|c|c|c|c|c|c|c|c|c|c|c|c|c|c|}
\hline Ko & & PB & $p$ & & & & (914 & $p l^{-}$ & 8 & & & 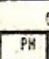 & $\frac{d e c t}{p t}$ & & & & & & & \\
\hline 1 & 4,5 & 2 & 7 & $\mathrm{n}$ & & & & & & & 4 & 2 & 6 &, 15 & & & 0 & 0 & & - \\
\hline 2 & & & & & & $?$ & 1 & 13 & ,9 & t. & 10,5 & 2 & 19 &, 437 &, 1 & 7,5 & 1 & 14 & 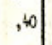 & , 1 \\
\hline 3 & 2 & 3 & 1 & , 11 & - & 2,5 & 1 & 4 & , 10 & & 8,5 & 1 & 16 & ,43 & , & & 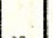 & & & \\
\hline$\therefore$ & $\begin{array}{c}3 \\
0.5\end{array}$ & 1 & ${ }_{18}^{3}$ &,$x$ & & & & & & & \begin{tabular}{|c|c}
4 \\
13
\end{tabular} & $\begin{array}{l}1 \\
6\end{array}$ & $\begin{array}{c}7 \\
20\end{array}$ & ,27) & & $\begin{array}{c}28,5 \\
5\end{array}$ & $\begin{array}{c}17 \\
17 \\
1\end{array}$ & $\begin{array}{l}40 \\
9\end{array}$ & & $1^{11}$ \\
\hline 5 & $\begin{array}{l}10,5 \\
16\end{array}$ & $\begin{array}{l}3 \\
7\end{array}$ & $\begin{array}{l}18 \\
{ }^{18}\end{array}$ & 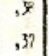 & $\begin{array}{l}1 \\
, 1\end{array}$ & 1,5 & 0 & 3 &, 27 & 1 & ${ }^{13}$ & ${ }^{6}$ & 20 & & & & 0 & 1 & & 20 \\
\hline ? & 5 & 5 & 5 & $\therefore 7$ & & 4 & 3 & 5 &, 07 & - & 5 & 0 & 10 &, 44 &, 1 & & & & & \\
\hline 8 & 1,5 & 2 & 1 & .09 & - & 8,5 & 2 & 15 &, 36 & $\because$ & & , & & & & 4 & 1 & 18 & ,227] & \\
\hline 9 & & & & & & 7,5 & 2 & 13 &, 31 & $P_{1}^{1}$ & ${ }_{3}^{5} .5$ & 3 & 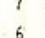 & ].1., & 5 & & ${ }^{1}$ & 13 & & , \\
\hline 10 & 1 & 3 & $?$ & ${ }^{, x}$ & 5 & $\begin{array}{c}13,5 \\
5\end{array}$ & 4 & ${ }^{23}$ & , & $4_{5}^{, 1}$ & $\begin{array}{c}3,5 \\
4\end{array}$ & $\left.\begin{array}{l}1 \\
1\end{array}\right]$ & ? & ,2127 & 5 & & & & & \\
\hline $\begin{array}{l}11 \\
12\end{array}$ & 3,5 & 2 & 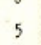 & ,121 & - & 3 & & & & & 9,5 & $?$ & 12 & , & - & 9,5 & 6 & 13 & & 20 \\
\hline 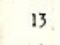 & 12,5 & 10 & 15 & .11 & - & 3,5 & 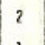 & 5 &, 12 & - & 97 & 5 & 13 & 20 & 5 & & & & & \\
\hline 14 & 3 & 0 & 6 & 37 &, 1 & 5 & 1 & 9 & , 30 & & & & & & & 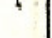 & 10 & 8 &, 11 & , 1 \\
\hline 15 & & 13 & 5 & ${ }^{20}$ & 5 & 5,5 & $\because$ & ${ }^{11}$ &., 47 & ${ }_{5}^{, 1}$ & ${ }^{10,5}$ & i & 20 & .501 &, 1 & 4,5 & 11 & 8 & & 1 \\
\hline $\begin{array}{l}16 \\
17\end{array}$ & 4,5 & 1 & 3 &, 27 & & & & , & & & 4,5 & $i$ & 8 &,$n$ & & 3,5 & 0 & $?$ &, 0 & 1 \\
\hline${ }_{18}$ & 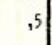 & 0 & . &, 15 & & 5,3 & 3 & 8 &, 16 & 20 & 11 & ${ }^{14}$ & 8 & ,14 & 20 & & & & & \\
\hline 19 & 9 & 8 & 10 & ,05 & - & & & & & & 5 & 3 & 7 & ,16 & 20 & 7,5 & 4 & n & & 5 \\
\hline 20 & & 2 & 6 & ${ }^{26}$ & 1 & 5 & 1 & ? & 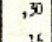 & $m_{m}^{1}$ & 65 & 1 & 18 & ${ }_{36} 6$ & 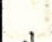 & & 1 & 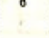 & & \\
\hline $\begin{array}{l}21 \\
22\end{array}$ & $\begin{array}{l}2 \\
4,5\end{array}$ & 8 & 1 & , & 1 & 8,5 & ro & 17 &, 60 & 1. & & & & & & & 1 & & & \\
\hline 23 & 5 & 6 & 4. & ,04 & - & & & & & - & & & & & & 7,5 & 8 & & & \\
\hline 25 & $\begin{array}{l}2,5 \\
0\end{array}$ & $\begin{array}{l}1 \\
0\end{array}$ & 0 & .100 & & & & & & & $\begin{array}{l}3 \\
7,5\end{array}$ & $\left|\begin{array}{l}0 \\
5\end{array}\right|$ & $\begin{array}{l}6 \\
10\end{array}$ & ,37 & $1^{11}$ & $\begin{array}{l}4,5 \\
10,5\end{array}$ & 9 & $\begin{array}{c}? \\
12\end{array}$ & $\begin{array}{l}18 . \\
, 08\end{array}$ & ${ }^{20}-$ \\
\hline
\end{tabular}




\section{APPENDIX B}

TABLE $B-5$

DISTRACTOR ANALYSIS - ENGLISH VOCABULARY TEST

\begin{tabular}{|c|c|c|c|c|c|c|c|c|c|c|c|c|c|c|c|c|c|c|c|c|c|c|c|c|c|}
\hline no & \multicolumn{5}{|c|}{ Chuice 1} & \multicolumn{5}{|c|}{ Croice 2} & \multicolumn{5}{|c|}{ Choice? } & \multicolumn{5}{|c|}{ Choice 4} & \multicolumn{5}{|c|}{ Cholee 5} \\
\hline & PI & $\mathrm{PH}$ & $\mathrm{Pt}$ & 0 & 3 & $P$ & PH & $\mathrm{PL}$ & 0 & $s$ & PI & PH & $\mathrm{PI}$ & 0 & $s$ & $\mathrm{PI}$ & PM & $p$ & 0 & 5 & $\mathrm{PT}$ & PU & $\mathrm{pl}$ & 0 & $s$ \\
\hline 1 & 0 & 0 & 0 & 0 & - & 2,5 & 4 & 1 & , 1 & - & & & & & & 15 & 8 & 22 & & 1 & .5 & 0 & 1 & & 5 \\
\hline 2 & 8 & 3 & 13 & .29 & $r$ & 3 & 1 & $s$ &, 2 & 5 & & & & & & 14,5 & 19 & 10 & & 10 & 2,5 & 2 & 3 &, 04 & - \\
\hline 3 & 2 & 2 & 2 & 0 & - & 5,5 & 0 & 11 & ,50 &, 1 & 64,5 & 81 & 48 & .47 &, 1 & 6 & 1 & 11 & .35 &, 1 & & & & & \\
\hline 4 & & & & & &, 5 & 0 & 1 & .15 & & 3,5 & 3 & 4 &, 11 & - & 11,5 & 1 & 22 & .56 &, 1 & 1,5 & 0 & 3 &, 3 & 1 \\
\hline 5 & 5 & 3 & 7 &, 18 & & & & & & & 1,5 & 1 & 2 & $\infty$ & - & 3,5 & 5 & 2 &, 1 & - & 1 & 0 & 2 &, 2 & 5 \\
\hline 6 & .5 & 0 & 1 &, 15 & & & & & & & 1 & 0 & 2 &, 2 & 5 & 5 & 0 & 1 &, 15 & 10 & 1 & 1 & 1 & 0 & - \\
\hline 7 & & & & & & 39 & 29 & 47 & 3 & 1 & 1 & 0 & 2 &, 2 & 5 & 8 & 6 & 10 & .1 & -1 & 12 & 17 & 7 & .2 & 5 \\
\hline 8 & 15 & 18 & 12 &, 1 & - & & & & & & 11,5 & 8 & 15 &, 19 & 5 & 12 & 15 & 9 &, 11 & -1 & 3,5 & 2 & 5 &, 15 & 10 \\
\hline 9 & 4 & 0 & ${ }^{8}$ &, 41 &, 1 & & & & & &, 5 & 0 & 1 &, 151 & 10 & 5 & 0 & 10 & .68 &, 1 & 1 & 0 & 2 &, 2 & 5 \\
\hline 10 & & & & & & 17,5 & 5 & 30 & .50 &, 1 & 4,5 & 0 & 9 & , 4 &, 1 & 3,5 & 0 & 7 & .6 &, 1 &, 5 & 0 & 1 &, 15 & 10 \\
\hline n & & & & & & 10 & 1 & 19 & .52 &, 1 & 6 & 2 & 10 &, 27 & 1 & 4 & 0 & 8 & ,41 &, 1 & 3,5 & 5 & 2 &, 15 & 10 \\
\hline 12 & 6 & 8 & 4 & , & - & & & & & & 6 & 8 & 4 &, 1 & - & 14,5 & 10 & 19 &,$^{2}$ & 5 & 4,5 & 7 & 2 & .16 & 20 \\
\hline 13 & 1,5 & 0 & 3 & .29 & 1 & 8,5 & 3 & 14 &, 31 & 1 & & & & & & 6 & 9 & 3 & , 15 & 20 & $B$ & 3 & 13 & 3 & 1 \\
\hline 14 & 6 & 3 & 9 & ,21 & 5 & 9 & 9 & 9 & 0 & - & & & & & & 11 & 7 & 15 &,$^{2}$ & 5 & 2 & 2 & 2 & 0 & - \\
\hline 15 & 6,5 & 7 & 6 & , 01 & - & 5 & 1 & 9 &, 3 & 1 & & & & & & 1,5 & 0 & 3 &, 29 & 1 & 2 & 1 & 3 &, 11 & - \\
\hline 16 & 21,5 & 21 & 22 & ,01 & - & 4,5 & 0 & 9 &, $4+4$ &, 1 & 3,5 & 0 & 7 & .4 &, 1 & & & & & & 1,5 & 0 & 3 &, 29 & 1 \\
\hline 17 & 4,5 & 4 & 5 & .03 & - & 0 & 0 & 0 & 0 & - & & & & & & 4 & 2 & 6 & & 20 & 1,5 & 1 & 2 &.,$\infty$ & - \\
\hline 18 & & & & & & 7,5 & 6 & 9 &, 1 & - & 2,5 & 0 & 5 & ,34 &, 1 & 2,5 & 0 & 5 & , 3h &, 1 & 1,5 & 0 & 3 &,$x$ & 1 \\
\hline 19 & 5 & 0 & 1 & .15 & 10 & 4 & 0 & B &, 41 & 11 & & & & & & 4 & 0 & 8 & ,41 &, 1 & 3 & 5 & 1 &, 15 & 10 \\
\hline 20 & 3 & 0 & 6 & .37 &, 1 & 9 & 3 & 15 & 34 & , & 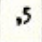 & 0 & & & & & & & & & 0 & 0 & 0 & 0 & - \\
\hline
\end{tabular}


Anastasi, A. Psychological Testing. New York: MacMillan, 1961.

Biesheuvel, S. The measurement of intelligence and aptitudes of African people. Scientific Conference, Communication No. (N) 4, 1949.

Biesheuvel, S. Personal communication. 1973.

Botha, W.C. Biographical Characteristics of the Successful Life Assurance Representative. UOFS. Personnel Research Div. 1972.

Botha, W.C. Distractor-Analysis for Multiple-Choice Test Items. Ford Hare Papers, 1976, 6(3) 2 - 233.

Bowd, A.D. The structure of Mechanical Aptitude in several cultural environments. Canadian Psychological Association. 1972.

Bowd, A.D. A cross-cultural study of functional composition of mechanical aptitude. Canadian Journal of Behavioral Sciences, 1973, 5.

Chapman, R.L. The MacQuarrie Test for Mechanical ability. Psychometrica, 1948, 3.

Cox, J.W. Mechanical Aptitude. London: Methuen and Co., 1928.

Fleishman, E.A. and Ellison, G.D. A factor analysis of five manipulative tests. Journal of Applied Psychology, 1962, 6.

Fleishman, E.A. and Hempel, W. E. Changes in factor structure of a complex psychomotor test as a function of practise. Psychometrica, 1954, 19.

Goodman, C.H. The MacQuarrie Test of Mechanical Ability 1: Selecting radio assembly operators. Journal of Applied Psychology, 1943, 30.

Harrel, W. A Factor Analysis of Mechanical Ability Test. Psychometrica, 1940, 5.

H S R C Test Catalogue. 1977.

Jenkins, W.L. An improved short-cut method for Multiple R. Educational and Psychological Measurement, 1952, 12.

Keane, F.L. and O'Connol, J. A measure of mechanical aptitude. Personnel Journal, 1927, 6.

Langenhoven, H.P. Intergroup Comparison in Psychological Measurement. Pretoria, N.C.S.R., 1963.

Lawshe, C.H. and Balma, M.J. Principles of Personnel Testing. New York: McGraw-Hill, 1966.

McCormick, E.J. and Tiffin, J. Industrial Psychology. London: Allen and Unwin, 1975.

Moore, M.R. A Handbook on the Principles and Procedures of Group Test Administration. No. 1068. Johannesburg: N.I.P.R., 1959.

N.I.P.R. Test Catalogue. 1977.

Nunnally, J.C. Introduction to Psychological Measurement. New York; McGraw-Hill, 1970. 